\title{
Innovation in Utilizing Pineapple Waste for Making Jam by Effect of Addition of Maizena Flour and Palm Sugar
}

\author{
Mauliza Agustina ${ }^{1 *}$, Salfauqi Nurman ${ }^{1}$, Ruka Yulia $^{2}$ \\ ${ }^{1}$ Program Studi Teknik Industri Pertanian, Fakultas Teknologi Pertanian, Universitas Serambi Mekkah \\ ${ }^{2}$ Program Studi Teknologi Pangan, Fakultas Teknologi Pertanian, Universitas Serambi Mekkah \\ *email:lizhaajha69@yahoo.com
}

\section{Article Info}

Article history:

Received

05/18/2019

Received in revised

05/18/2019

Accepted

05/19/2019

\begin{abstract}
The purpose of this study was to determine the effect of adding cornstarch and palm sugar to the quality of pineapple pulp and to determine the best treatment and variable influence on processing pineapple pulp. The variables used were addition of cornstarch (2\%, $5 \%$ and $5 \%$ ), with the addition of palm sugar $(20 \%, 30 \%$ and $40 \%)$. While the parameters analyzed are moisture content, organoleptic test (color, aroma, taste, texture), topping and sugar content. The research data were processed using Factorial Completely Randomized Design (RAL) with 2 replications, data analysis with ANOVA and the Smallest Significant Difference Advanced Test (LSD). The best treatment in this study is the treatment of Z1G3 SNI quality requirements for pineapple pulp 3726-2008 in general the water content is $\max 20 \%$ with a moisture content value of $46.47 \%$, organoleptic test color value 3.90 (somewhat like), aroma value 4.13 (likes), taste 4.37, texture 4.17 (likes), topical power of $4.04 \%$ and SNI max sugar content of $45 \%$ in the research produced $26.47 \%$ sugar content.
\end{abstract}

Keywords: Pineapple Pulp, Jam, Addition of Maizena Flour and Palm Sugar

\section{Inovasi Pemanfaatan Limbah Ampas Nanas untuk Pembuatan Selai dengan Pengaruh Penambahan Tepung Maizena dan Gula Aren}

\begin{abstract}
Abstrak
Tujuan penelitian ini adalah untuk mengetahuai pengaruh penambahan tepung maizena dan gula aren terhadap mutu selai ampas nanas serta menentukan perlakuan terbaik dan pengaruh variabel pada pengolahan selai ampas nanas. Variabel yang digunakan ialah penambahan tepung maizena $(2 \%, 5 \%$ dan 5\%), dengan penambahan gula aren $(20 \%, 30 \%$ dan $40 \%)$. Sedangkan Parameter yang dianalisis adalah Kadar Air, Uji Organoleptik (Warna, Aroma, Rasa, Tekstur), Daya Oles dan Kadar Gula. Data hasil penelitian diolah dengan menggunakan Rancangan Acak Lengkap (RAL) Faktorial dengan 2 ulangan, analisis data dengan ANOVA dan Uji Lanjut Beda Nyata Terkecil (BNT). Perlakuan terbaik pada penelitian ini adalah perlakuan Z1G3 syarat mutu SNI selai ampas nanas 3726-2008 secara umum kadar air maks $20 \%$ dengan nilai kadar air 46,47\%, uji organoleptik nilai warna 3,90 (agak suka), nilai aroma 4,13 (suka), rasa 4,37, tekstur 4,17 (suka), daya oles 4,04\% serta SNI kadar gula maks $45 \%$ dalam penelitian dihasilkan kadar gula 26,47\%.
\end{abstract}

Kata kunci: Ampas Nanas, Selai, Penambahan Tepung Maizena dan Gula Aren 


\section{PENDAHULUAN}

Ampas nanas didapat dari sisa hasil pembuatan sirup nanas, jelly, sari buah. Selama ini, ampas nanas tidak dimanfaatkan secara optimal, dan hanya menjadi limbah dan dibuang begitu saja. Padahal ampas tersebut bisa dimanfaatkan lagi dan bisa diolah menjadi makanan atau selai dari ampas nanas tersebut, limbah ampas nanas masih dapat dimanfaatkan dalam pembuatan makanan karena limbah tersebut banyak mengandung serat. Serat makanan dapat mengikat garam-garam empedu yaitu zat yang berfungsi menyerap lemak didalam saluran pencernaan. Jika kita banyak serat, maka garam empedu tersebut sebelum mengabsorbsi lemak, telah terikat oleh serat dan kemudian bersama-sama serat tersebut dikeluarkan dalam bentuk feses. Berkurangnya absorbsi lemak akan menyebabkan kadar kolestrol didalam tubuh akan turun. Selain itu, secara mekanis serat juga dapat menghalangi penyerapan zat-zat gizi lainnya seperti karbohidrat dan protein. Ampas nanas mengandung gula, mineral dan vitamin, sehingga berpotensi sebagai sumber karbon dan mineral (Manoi, 2007).

Herdis dan Muhammad (2001) menyatakan bahwa hasil analisa proksimat yang dilakukan menunjukkan bahwa kandungan nutrisi limbah nanas yang berasal dari ampas nanas adalah kadar abu 1,28\%, vitamin C 19,8 miligram/100 gram, protein $9,71 \%$, lemak $6,08 \%$, dan serat kasar 22,45\%. Berdasarkan hasil penelitian tersebut, ampas nanas berpotensi untuk dimanfaatkan menjadi produk inovatif bernilai ekonomis tinggi.

Proses pembuatan minuman sari nanas banyak menghasilkan ampas nanas, pengetahuan masyarakat tentang pengolahan ampas nanas untuk dijadikan suatu produk yang memiliki nilai ekonomis masih kurang. Selai ampas nanas adalah salah satu jenis makanan olahan yang dapat dibuat dari ampas nanas.

Gula aren umumnya sebagai pemanis alami dan memiliki cita rasa yang khas dibandingkan dengan gula biasa pada umumnya. Gula aren tidak secara langsung larut dalam tubuh, namun diserap secara perlahan, oleh karenanya gula aren dapat bertahan lama dalam tubuh. Sehingga tidak secara langsung meningkatkan kadar gula dalam tubuh. Gula aren juga aman dikonsumsi oleh penderita diabetes. Tujuan penambahan gula dalam pembuatan selai adalah untuk memperoleh tekstur, penampakan, dan flavor yang ideal. Selain itu gula dapat juga berfungsi sebagai pengawet (Yulia, 2006). Penggunaan gula aren untuk pembuatan selai telah pernah di lakukan oleh Jariah (2014). Dari hasil penelitian tersebut penggunaan variasi gula aren yang optimal pada 150 gram dengan berat bahan 500 gram sehingga presentasi gula aren yang digunakan adalah 30\% padapengaruh penambahan karboksi metil selulosa (CMC) dan tingkat kematangan buah nanas (Ananas Comocus (L) Merr) terhadap mutu selai nanas.

Maizena sering digunakan sebagai pengganti fungsi pektin dalam proses pembuatan produk pangan, yaitu sebagai pengental. Pektin adalah golongan substansi yang terdapat dalam sari buah, yang membentuk larutan koloidal dalam air dan berasal dari perubahan protopektin selama proses pemasakan buah. Pektin sangat penting dalam pembuatan selai karena pektin berfungsi sebagai pembentuk kekentalan (Fitriani, 2013).

Berdasarkan penelitian Sari (2011). Pembuatan selai dari belimbing dengan penambahan tepung maizena dimana perlakuan yang diberikan dalam penelitian ini adalah sebagai berikut: $\mathrm{A}=$ tanpa 
perlakuan, $\mathrm{B}=$ penambahan maizena dengan konsentrasi $5 \%, \mathrm{C}=$ penambahan maizena dengan konsentrasi 10\%, $\mathrm{D}=$ penambahan maizena dengan konsentrasi $15 \%, \mathrm{E}=$ Penambahan maizena dengan konsentrasi 20\%. Dimana penambahan maizena dengan konsentrasi 5\% adalah perlakuan yang terbaik.

Berdasarkan literatur diatas, maka dilakukan penelitian pembuatan selai ampas nanas dengan memanfaatkan limbah ampas nanas yang ditambah tepung maizena sebagai pengganti fungsi pektin serta gula aren sebagai pemanis dan pengawet. Penelitian ini akan di lakukan dengan menvariasikan tepung maizena dan gula aren yang bertujuan untuk menentukan kondisi optimum terhadap pembuatan selai.

Penelitian bertujuan untuk mengetahui pengaruh penambahan tepung maizena dan gula aren terhadap mutu selai ampas nanas serta mengetahui interaksi antara penambahan tepung maizena dan gula aren terhadap mutu selai ampas nanas.

\section{METODE PENELITIAN}

\section{Lokasi dan Waktu Penelitian}

Penelitian ini dilakukan di Laboratorium Pengolahan Hasil Pertanian Fakultas Teknologi Pertanian Universitas Serambi Mekkah, pada bulan Oktober 2017 sampai Desember 2017 dan di analisa di Laboratorium Balai Riset Dan Standardisasi Industri Banda Aceh.

\section{Alat dan Bahan}

Alat-alat yang digunakan dalam penelitian ini adalah: blender, baskom, panci, pengaduk, pisau, talenan, sendok, botol, kompor, oven, dan wajan.

Bahan-bahan yang digunakan dalam penelitian ini adalah ampas nanas, gula aren, air $200 \mathrm{ml}$ dan tepung maizena.

\section{Rancangan Percobaan}

Menurut penelitian (Bangun, 2008) pengumpulan data dan analisa pada penelitian ini menggunakan Rancangan Acak Lengkap (RAL) faktorial, dengan dua faktor yang diteliti yaitu pengaruh penambahan tepung maizena ( $Z$ ) dan penambahan gula aren $(G)$ terhadap selai ampas nanas. Adapun faktor - faktor yang diteliti adalah sebagai berikut :

Faktor 1 : konsentrasi tepung maizena $(\mathrm{Z})$ yang terdiri dari 3 level, yaitu :

$\mathrm{Z}_{1}=2 \%$

$\mathrm{Z}_{2}=5 \%$

$\mathrm{Z}_{3}=8 \%$

Faktor 2 :gula aren $(G)$ yang terdiri dari 3 level, yaitu :

$\mathrm{G}_{1=20} \%$

$\mathrm{G}_{2}=30 \%$

$\mathrm{G}_{3}=40 \%$

Dengan demikian terdapat 9 kombinasi perlakuan yang dicoba dan masing-masing diulang sebanyak 2 kali, sehingga diperoleh 18 unit dengan susunan kombinasi perlakuan seperti yang terlihat pada Tabel 1.

Tabel 1. Kombinasi Perlakuan

\begin{tabular}{cccc}
\hline \multirow{2}{*}{$\begin{array}{c}\text { Penambahan } \\
\text { tepung } \\
\text { maizena }(\mathbf{Z})\end{array}$} & \multicolumn{3}{c}{$\begin{array}{c}\text { Penambahan gula aren } \\
(\mathbf{G})\end{array}$} \\
\cline { 2 - 4 } & $\mathbf{G 1}$ & $\mathbf{G 2}$ & $\mathbf{G 3}$ \\
$\mathbf{( 2 0 \% )}$ & $(\mathbf{3 0 \%})$ & $\mathbf{( 4 0 \% )}$ \\
\hline $\mathrm{Z}_{1}=2 \%$ & $\mathrm{Z}_{1} \mathrm{G}_{1}$ & $\mathrm{Z}_{1} \mathrm{G}_{2}$ & $\mathrm{Z}_{1} \mathrm{G}_{3}$ \\
$\mathrm{Z}_{2}=5 \%$ & $\mathrm{Z}_{2} \mathrm{G}_{1}$ & $\mathrm{Z}_{2} \mathrm{G}_{2}$ & $\mathrm{Z}_{2} \mathrm{G}_{3}$ \\
$\mathrm{Z}_{3}=8 \%$ & $\mathrm{Z}_{3} \mathrm{G}_{1}$ & $\mathrm{Z}_{3} \mathrm{G}_{2}$ & $\mathrm{Z}_{3} \mathrm{G}_{3}$ \\
\hline
\end{tabular}

Setelah data diperoleh, selanjutnya dianalisis secara statistic dengan menggunakan ANOVA (Analysis of Variance). Bila uji perlakuan menunjukkan pengaruh yang nyata antar perlakuan maka akan diteruskan dengan uji lanjut Beda Nyata Terkecil (BNT). 


\section{Prosedur Penelitian}

Cara pembuatan selai ampas nanas sebagai berikut (Syahrumsyah, 2010):

1. Ampas nanas yang masih segar di timbang sebanyak $100 \mathrm{~g}$.

2. Kemudian di kukus selama satu jam, agar ampas nanas lebih awet.

3. Ampas nanas yang telah dikukus dicampur dengan tepung maizena sesuai dengan perlakuan $\left(Z_{1}=2 \%, Z_{2}\right.$ $=5 \%, Z_{3}=8 \%$ ) dan penambahan gula aren sesuai dengan perlakuan $\left(\mathrm{G}_{1}=\right.$ $20 \%, \mathrm{G}_{2}=30 \%, \mathrm{G}_{3}=40 \%$ ).

4. Kemudian bahan yang telah tercampur ditambah air sebanyak $200 \mathrm{ml}$.

5. Setelah semua bahan tercampur dimasak dalam wajan selama 30 menit.

6. Setelah masak diangkat dan didinginkan selama 10 menit.

7. Kemudian selai dikemas dengan menggunakan plastik dan analisis.

\section{Prosedur Analisa}

Pengamatan dan pengukuran data dengan cara analisa terhadap parameter yang terdiri dari kadar air, uji organoleptik (warna, rasa, aroma, dan tekstur), uji daya oles, dan kadar gula. Untuk uji organoleptik dan uji daya oles dilakukan dengan menggunakan panelis sebanyak 15 panelis secara inderawi dan di tentukan berdasarkan skala numerik

\section{HASIL DAN PEMBAHASAN Kadar Air}

Berdasarkan data hasil penelitian diperoleh nilai rataan kadar air selai ampas nanas berkisar antara 43,50 - 67,18 dengan rata-rata 54,77. Nilai tertinggi kadar air selai ampas nanas diperoleh dari perlakuan penambahan tepung maizena $8 \%(\mathrm{Z3})$ dan gula aren $20 \%$ (G1) yaitu $67,18 \%$. Sedangkan nilai terendah perlakuan ini adalah pada penambahan tepung maizena
$8 \%$ (Z3) dengan gula aren $40 \%$ (G3) dengan nilai 43,50 (Tabel 2).

Tabel 2. Rata-rata Hasil Analisa Kadar Air Selai Ampas Nanas pada Tiap Taraf dengan Perbandingan Tepung Maizena dan Gula Aren.

\begin{tabular}{cccc}
\hline Konsentrasi & \multicolumn{3}{c}{ Gula Aren } \\
\cline { 2 - 4 } $\begin{array}{c}\text { Tepung } \\
\text { Maizena } \\
(\mathbf{Z})\end{array}$ & $\begin{array}{c}\text { G1 } \\
\mathbf{( 2 0 \% )}\end{array}$ & $\begin{array}{c}\text { G2 } \\
\mathbf{3 0 \% )}\end{array}$ & $\begin{array}{c}\text { G3 } \\
\mathbf{4 0 \%})\end{array}$ \\
\hline Z1 (2\%) & 61,67 & 54,25 & 46,47 \\
Z2 ( 5\%) & 58,84 & 59,68 & 48,18 \\
Z3 ( 8\%) & 67,18 & 53,15 & 43,50 \\
\hline
\end{tabular}

Hasil sidik ragam menunjukkan bahwa pengaruh penambahan tepung maizena $(Z)$ berpengaruh tidak nyata $(P \leq 0,05)$, gula aren $(\mathrm{G})$ berpengaruh nyata $(\mathrm{P} \geq 0,05)$ dan interaksi antara penambahan tepung maizena dengan gula aren terhadap selai ampas nanas (ZG) berpengaruh tidak nyata $(\mathrm{P} \leq 0,05)$ terhadap kadar air pada selai ampas nanas.

Selai ampas nanas yang ditambah tepung maizena $8 \%$ (Z3) dan gula aren 40\% (G3) mempunyai kadar air paling rendah. Artinya selai tersebut lebih tahan terhadap pertumbuhan mikroba yang dapat merusak selai. Penurunan jumlah kadar air pada makanan dapat menghambat laju kerusakan bahan makanan yang umumnya merupakan proses mikrobiologis, kimiawi, enzimatik atau kombinasi ketiganya yang berlangsung akibat tersedianya air di dalam bahan makanan tersebut (Winata, 2001).

Menurut Standar SNI, kadar air untuk selai maksimal 20\% (b/b). Apabila dibandingkan dengan standar kadar air selai secara umum tersebut, maka kadar air pada selai ampas nanas tidak sesuai dengan standar SNI yaitu minimal 43,50\% yang dihasilkan dari perlakuan penambahan 
tepung maizena $8 \%$ dan gula aren $40 \%$ (Z3G3) yaitu 43,50\%.

\section{Uji Organoleptik}

\section{Warna}

Dari hasil uji organoleptik warna diperoleh rata-rata tingkat kesukaan panelis terhadap warna selai ampas nanas adalah berkisar antara 3,44 (biasa) - 4,07 (suka), dengan rata-rata 3,88 (biasa) (Tabel 3).

Tabel 3. Rata-rata Hasil Analisa Warna Selai Ampas Nanas pada Tiap Taraf Perlakuan

\begin{tabular}{cccc}
\hline Penambahan & \multicolumn{3}{c}{ Gula Aren (G) } \\
\cline { 2 - 4 } Tepung & G1 & G2 & G3 \\
Maizena & $\mathbf{( 2 0 \% )}$ & $\mathbf{( 3 0 \% )}$ & $\mathbf{( 4 0 \% )}$ \\
\hline Z1 (2\%) & 3,44 & 4,00 & 3,90 \\
Z2 ( 5\%) & 3,57 & 3,90 & 4,20 \\
Z3 ( 8\%) & 3,17 & 3,24 & 3,40 \\
\hline
\end{tabular}

Nilai tertinggi pada perlakuan ini terdapat pada penambahan tepung maizena 5\% (Z2) dan gula aren 40\% (G3) dengan nilai 4,20 (suka). Sedangkan nilai terendah pada perlakuan ini adalah pada penambahan tepung maizena $8 \%(\mathrm{Z} 3)$ dan gula aren $20 \%$ (G1) dengan nilai 3,17 (biasa).

Analisa sidik ragam menunjukkan bahwa perlakuan penambahan tepung maizena (Z) dan interaksi penambahan maizena dan gula aren (ZG) terhadap selai ampas nanas berpengaruh tidak nyata $(\mathrm{P} \leq 0,05)$. Namun penambahan gula aren (G) berpengaruh nyata terhadap warna selai ampas nanas $(\mathrm{P} \geq 0,05)$.

Warna selai ampas nanas yang dihasilkan pada setiap perlakuan ialah krem mendekati putih. Menurut Purwanto (2013) hal ini disebabkan penambahan tepung maizena dan gula aren pada pembuatan selai dapat menghambat reaksi pencoklatan yang dikatalis enzim fenolase dan dapat memblokir reaksi pembentukan senyawa 5 hidroksil metal furfural dari Dglukosa penyebab warna coklat. Sedangkan kecoklatan yang biasanya dihasilkan pada selai merupakan reaksi browning non enzimatis dari penggunaan gula aren, yaitu reaksi karamelisasi pada gula yang disebabkan oleh pemanasan pada suhu tinggi (Anggraini, 2007).

\section{Aroma}

Dari hasil uji organoleptik aroma diperoleh rata-rata tingkat kesukaan panelis terhadap aroma selai ampas nanas adalah berkisar antara 3,60 (biasa)-4,13 (suka), dengan rata-rata 3,94 (biasa) (Tabel 4).

Tabel 4. Rata-rata Hasil Analisa Uji Organoleptik Aroma Selai Nanas

\begin{tabular}{cccc}
\hline Konsentrasi & \multicolumn{3}{c}{ Gula Aren (G) } \\
\cline { 2 - 4 } $\begin{array}{c}\text { Tepung } \\
\text { Maizena } \\
(\mathbf{Z})\end{array}$ & $\mathbf{G 1}$ & $\mathbf{G 2}$ & $\mathbf{G 3}$ \\
$\mathbf{( 2 0 \% )}$ & $\mathbf{( 3 0 \% )}$ & $\mathbf{( 4 0 \% )}$ \\
\hline Z1 ( 2\%) & 3,93 & 3,74 & 4,13 \\
Z2 ( 5\%) & 3,87 & 4,10 & 3,60 \\
Z3 ( 8\%) & 4,07 & 3,90 & 4,13 \\
\hline
\end{tabular}

Nilai terendah pada perlakuan ini terdapat pada konsentrasi maizena 5\% (Z2) dan gula aren 40\% (G3) dengan nilai 3,60 (suka). Sedangkan nilai tertinggi pada perlakuan ini adalah pada penambahan tepung maizena $8 \%$ dan $2 \%$ ( $\mathrm{Z} 1$ dan $\mathrm{Z3}$ ) dan gula aren $40 \%$ G3) dengan nilai 4,13 (suka).

Hasil sidik ragam menunjukkan bahwa penambahan tepung maizena (Z), penambahan gula aren $(G)$ dan interaksi antara penambahan tepung maizena dan 
gula aren pada selai ampas nanas (ZG) berpengaruh tidak nyata $(\mathrm{P} \leq 0,05)$ terhadap nilai organoleptik aroma selai ampas nanas.

Selai ampas nanas yang dihasilkan mengeluarkan aroma khas dari buah nanas, yang ditimbulkan. Aroma yang dikeluarkan dari ampas nanas merupakan senyawa volatil (senyawa kimia organik yang mudah menguap) terkandung didalam ampas nanas baik yang keadaan fluktatif maupun anerobik oleh mikroorganisme (Dewanti, 2008).

\section{Rasa}

Dari hasil uji organoleptik rasa diperoleh rata-rata tingkat kesukaan panelis terhadap warna selai ampas nanas adalah berkisar antara 3,53 (biasa) - 4,37 (suka), dengan rata-rata 4,06 (suka) (Tabel 5).

Tabel 5. Rata-rata Hasil Analisa Organoleptik Rasa Selai Ampas Nanas pada Tiap Taraf Perlakuan

\begin{tabular}{cccc}
\hline Penambahan & \multicolumn{3}{c}{ Gula Aren (G) } \\
\cline { 2 - 4 } Tepung \\
Maizena & G1 & G2 & G3 \\
$\mathbf{( Z )}$ & $\mathbf{( 2 0 \% )}$ & $\mathbf{( 3 0 \% )}$ & $\mathbf{( 4 0 \% )}$ \\
\hline Z1 ( 2\%) & 3,70 & 4,04 & 4,37 \\
Z2 ( 5\%) & 4,20 & 4,24 & 3,53 \\
Z3 ( 8\%) & 4,07 & 4,17 & 4,27 \\
\hline
\end{tabular}

Nilai orgaoleptik rasa tertinggi di peroleh pada penambahan tepung maizena $2 \%$ (Z1) dan gula aren $40 \%$ (G3) yaitu 4,37 (suka). Sedangkan nilai terendah terhadap kesukaan panelis terhadap rasa yaitu pada penambahan tepung maizena $5 \%$ (Z2) dan gula aren $40 \%$ (G3) yaitu 3,53 (biasa).

Hasil sidik ragam menunjukkan penambahan tepung maizena $(\mathrm{Z})$ dan gula aren $(\mathrm{G})$ berpengaruh tidak nyata $(\mathrm{P} \leq 0,05)$ namun interaksi penambahan tepung maizena dan gula aren ( $\mathrm{ZG}$ ) berpengaruh sangat nyata $(\mathrm{P} \geq 0,01)$ terhadap nilai organoleptik rasa selai nenas. Hal ini diduga kemungkinan disebabkan karena rasa dipengaruhi oleh interaksi dengan komponen rasa yang lain pada saat penambahan tepung maizena dan gula aren pada selai ampas nanas.

Penambahan tepung maizena pada selai sebagai bahan pengental selai. Sedangkan gula aren menyebabkan rasa manis pada selai lembaran. Semakin meningkat gula aren, selai lembaran semakin disukai oleh konsumen.

\section{Tekstur}

Dari hasil uji organoleptik tekstur diperoleh rata-rata tingkat kesukaan panelis terhadap warna selai ampas nanas adalah berkisar antara 3,54 (biasa) - 4,34 (suka), dengan rata-rata 3,96 (biasa) (Tabel 6).

Tabel 6. Rata-rata Hasil Analisa Organoleptik Tekstur Selai Ampas Nanas pada Tiap Taraf Perlakuan

\begin{tabular}{cccc}
\hline Penambahan & \multicolumn{3}{c}{ Gula Aren (G) } \\
\cline { 2 - 4 } $\begin{array}{c}\text { Tepung } \\
\text { Maizena }\end{array}$ & G1 & G2 & G3 \\
$\mathbf{( Z )}$ & $\mathbf{2 0 \% )}$ & $\mathbf{( 3 0 \% )}$ & $\mathbf{( 4 0 \% )}$ \\
\hline Z1 ( 2\%) & 3,67 & 3,94 & 4,17 \\
Z2 ( 5\%) & 4,34 & 3,54 & 4,07 \\
Z3 ( 8\%) & 4,07 & 3,90 & 3,93 \\
\hline
\end{tabular}

Nilai tertinggi diperoleh pada perlakuan penambahan tepung maizena $5 \%$ (Z2) dan gula aren 20\% (G1) dengan nilai 4,34 (suka). Sedangkan nilai terendah terdapat pada penambahan tepung maizena $5 \%$ (Z2) dan gula aren $30 \%(\mathrm{G} 2)$ dengan nilai 3,54 (biasa). 


\begin{tabular}{|c|c|c|c|c|}
\hline \multirow{5}{*}{$\begin{array}{l}\text { Hasil analisa sidik ragam } \\
\text { menunjukkan bahwa perlakuan } \\
\text { penambahan tepung maizena }(\mathrm{Z}) \text { dan gula } \\
\text { aren }(\mathrm{G}) \text { berpengaruh tidak nyata }(\mathrm{P} \leq 0,05) \\
\text { namun interaksi penambahan tepung } \\
\text { maizena dan gula aren }(\mathrm{ZG}) \text { berpengaruh } \\
\text { nyata }(\mathrm{P} \geq 0,05) \text { terhadap organoleptik }\end{array}$} & \multirow{2}{*}{$\begin{array}{c}\text { Penambahan } \\
\text { Tepung } \\
\text { Maizena } \\
(\mathbf{Z}) \\
\end{array}$} & \multicolumn{3}{|c|}{ Gula aren $(\mathbf{G})$} \\
\hline & & $\begin{array}{c}\text { G1 } \\
(20 \%)\end{array}$ & $\begin{array}{c}\text { G2 } \\
(30 \%)\end{array}$ & $\begin{array}{c}\text { G3 } \\
(40 \%)\end{array}$ \\
\hline & Z1 ( $2 \%)$ & 3,47 & 3,77 & 4,04 \\
\hline & $\mathrm{Z2}(5 \%)$ & 4,20 & 3,44 & 4,04 \\
\hline & $\mathrm{Z3}(8 \%)$ & 4,04 & 3,84 & 3,80 \\
\hline
\end{tabular}

Pada perlakuan yang paling disukai, selai ampas nanas yang dihasilkan memiliki tekstur yang lebih lembut. Hal ini disebabkan karena penambahan tepung maizena menyebabkan terbentunya gel dalam selai. Penambahan gula aren menyebabkan pengikatan air menjadi lebih banyak sehingga membuat tekstur pada selai ampas nanas semakin lunak dan disukai oleh konsumen.

Hal ini juga di dukung oleh Fitriani (2013), bahwa tepung maizena sebagai pembentuk gel dapat memperkeras tektur jika dilakukan penambahan terlalu banyak. Menurut Lisdiana, F (1997), pengikatan air yang dilakukan gula aren yang banyak dapat membuat tekstur dalam selai menjadi lebih lunak.

Penambahan tepung maizena dan gula aren dengan konsentrasi yang berbeda berbanding sama, dengan semakin tinggi konsentrasi tepung maizena dan gula yang ditambahkan maka tekstur yang dihasilkan semakin terasa keras pada saat di sentuh.

\section{Daya Oles}

Uji organoleptik daya oles selai nenas dilakukan pada roti tawar. Dari hasil uji organoleptik daya oles diperoleh nilai antara 3,44 - 4,20 (biasa-suka), dengan rata-rata 3,85 (biasa) (Tabel 7).

Tabel 7. Rata-rata Hasil Analisa Organoleptik Daya Oles Selai Ampas Nanas terhadap Penambahan Tepung Maizena dan Gula Aren

Daya oles yang paling baik pada penambahan tepung maizena dan gula aren pada konsentrasi terendah yaitu tepung maizena 5\% (Z2), dan gula $20 \%$ (G1) yaitu 4,20 (suka). Sedangkan penambahan tepung maizena $2 \%(\mathrm{Z1})$ dan gula 20\% (G1) diperoleh daya oles adalah 3,47 (biasa). Konsentrasi maizena dan gula yang lebih rendah menghasilkan daya oles selai nenas yang kurang baik (selai nenas sulit untuk di oleskan pada roti).

Hasil sidik ragam menunjukkan penambahan tepung maizena ( $\mathrm{Z}$ ) dan penambahan gula aren $(\mathrm{G})$ berpengaruh tidak nyata $(\mathrm{P} \leq 0,05)$ namun interaksi penambahan tepung maizena dan gula aren (ZG) berpengaruh nyata $(\mathrm{P} \geq 0,05)$ terhadap nilai organoleptik daya oles selai ampas nenas.

Penambahan tepung maizena pada jumlah yang seimbang menyebabkan pembentukan gel yang sedikit dan penambahan gula aren menyebabkan pengikatan air menjadi lebih banyak sehingga membuat daya oles pada selai ampas nanas semakin halus dan disukai oleh konsumen.

\section{Kadar Gula}

Analisis kadar gula hanya dilakukan pada perlakuan penambahan tepung maizena $2 \%$ dengan gula aren $20 \%$ (Z1G1). Kadar gula yang dihasilkan yaitu $10,62 \%$, penambahan tepung maizena $2 \%$ dengan gula aren $30 \%$ (Z1G2) kadar gula 
yang dihasilkan yaitu 22,67\%, dan penambahan tepung maizena $2 \%$ dan gula aren $40 \%$ kadar gula yang dihasilkan yaitu 26,47\% (Z1G3). Menurut SNI No.37262008. Kadar gula selai buah yaitu minimal 45\%. Hal ini menunjukkan bahwa kadar gula selai ampas nanas dalam penelitian ini belum memenuhi persyaratan mutu selai ampas nanas dari SNI.

Menurut Indriyani (2007) hal ini disebabkan dengan proses pemanasan akan menyebabkan komponen serat pangan terhidrolisis atau terdegradasi agar mudah larut, penambahan tepung maizena akan meningkat air bebas untuk pembentukan selai sehingga jumlah glukosa yang larut berkurang. Pada penelitian ini, hal tersebut juga berpengaruh terhadap gula yang di subtitusikan yaitu dengan menggunakan gula aren. Karena glukosa gula aren secara umum 70-79\% sedangkan dengan gula pasir yang memiliki kadar glukosa 99,9\%100\% (Anindya, 2017).

Semakin tinggi penambahan gula aren kadar gula yang dihasilkan menjadi semakin tinggi yaitu mencapai $26,47 \%$ pada penambahan tepung mizena $2 \%$ dan gula aren $40 \%$ (Z1G3), namun jika dilihat dari standar SNI secara umum kadar gula pada penelitian ini belum memenuhi SNI karena secara umum kadar gula menurut standar nasional yaitu min $45 \%$, hal itu berlaku pada kadar glukosa gula pasir, namun pada penelitian ini menggunakan gula aren, kadar glukosa pada gula aren lebih rendah hingga 20-30\% dibandingkan dengan gula pasir yang memiliki kadar glukosa 99,9-100\%.

\section{KESIMPULAN}

Perlakuan terbaik pada penelitian ini adalah pada perlakuan Z1G3 syarat mutu SNI selai ampas nanas 3726-2008 secara umum kadar air maks $20 \%$ dengan nilai kadar air 46,47\%, uji organoleptik nilai warna 3,90 (agak suka), nilai aroma 4,13 (suka), rasa 4,37, tekstur 4,17 (suka), daya oles 4,04\% serta SNI kadar gula maks $45 \%$ dalam penelitian dihasilkan kadar gula $26,47 \%$.

\section{DAFTAR RUJUKAN}

Anindya, 2017. Pengaruh Konsentrasi Asam Sitrat Dan Lama Pemanasan Terhadap Karakteristik Kimia Dan Organoleptik Sirup Alang-Alang (Imperata cylindrica). Jurnal Pangan dan Agroindustri Vol. 4 No 1 p.180-189, Januari 2016

Anggraini, 2007. Pembuatan Selai Lembaran Terong Belanda (The Making Of Slice Jam From Belanda Eggplant. Sikripsi Universitas Padjajaran.

Fitriani, 2013. Pengaruh proporsi pektin dan asam sitrat sebagai bahan pembentuk jelly. Skripsi. Fakultas pertanian. Universitas Andalas. Padang.

Herdis dan R.A. Muhammad. 2001. Pemanfaatan Limbah Nenas Sebagai Pakan Ternak dan Pengarunya Terhadap Kualitas Semen Beku. Proseding Seminar Keanekaragaman Hayati dan Aplikasi Bioteknologi Pertanian. Jakarta.

Indriyani, 2007. Pengaruh Penambahan Asam Sitrat dan Karaginan terhadap Mutu Selai Apel Lembaran. Skirpsi Jurusan Teknologi Pangan. Universitas Pembangunan Nasional "Veteran" Jawa Timur. Surabaya.

Jariyah, U. N. 2014. Uji Organoleptik Dan Daya Simpan Selai Krokot (Portulaca Oleracea) Dengan Pewarna Sari Buah Naga Merah Dan Penambahan Jahe Serta Gula Aren Dengan Konsentrasi Yang Berbeda. Skripsi. Program Studi 


\begin{tabular}{cc}
\hline Pendidikan Biologi. Universitas & Syahrumsyah, H. W. Murdianto,. N. \\
Muhammadiyah. Surakarta. & Pramantu. $2010 . \quad$ Pengaruh \\
Lisdiana F., 1997. Membuat Aneka Selai. & Penambahan Karboksi Metil \\
Penerbit Karnisius. Yogyakarta. & Selulosa (CMC) dan Tingkat \\
Manoi, F., 2007. Penambahan Ektrak & Kematangan Buah Nanas (Ananas \\
Ampas Nanas Sebagai Medium & Comosus (L) Merr.) Terhadap mutu \\
Campuran Pada Pembuatan NataDe & selai nanas. Jurnal Fakultas \\
Cashew. Balai Penelitian Tanaman & Pertanian. Universitas Mulawarman.
\end{tabular}
Obat Dan Aromatik. Hal 107-116.

Purwanto, 2013. Pembuatan Selai Lembaran Terong Belanda (The Making Of Slice Jam From Belanda Eggplant. Sikripsi Universitas Padjajaran.

Standar Nasional Indonesia, 1995. Gula Palma (SNI 01-3743-1995. Pusat Standarisasi Industri. Departemen Perindustrian. Jakarta

Winata, A. Y.2001. Karakteristik Tepung Sukun (Artocarpus ultilis) Pramasak Hasil Pengeringan Drum Serta Aplikasinya Untuk Subtitusi Tepung Terigu Pada Pembuatan Roti Manis.IPB, Bogor.

Yulia A., 2006. Pengaruh Penambahan Gula Terhadap Sifat Kimia dan Organoleptik Manisan Kering Nanas Tangkit. Jurnal Teknologi dan Industri Hasil Pertanian. 5 (2:6:2326) 